\title{
Investigating the Female Subaltern, Colonial Discourse and False Consciousness: A Spivakian Marxist-Postcolonialist Reading of Chinua Achebe's Things Fall Apart and No Longer at Ease
}

\author{
Jalal Mostafaee \\ Department of English Literature and Linguistics, Faculty of Literature and Foreign Languages, University of Kurdistan, Iran \\ E-mail: jalal_4pk@yahoo.com
}

Doi:10.7575/aiac.alls.v.7n.5p.222

URL: http://dx.doi.org/10.7575/aiac.alls.v.7n.5p.222
Received: 22/06/2016

Accepted: $31 / 08 / 2016$

\begin{abstract}
The present research study attempts to investigate Chinua Achebe's Things Fall Apart and No Longer at Ease in terms of Gayatri Spivak Marxist-Post colonialist conceptions of subaltern, colonial discourse and false consciousness. In Postmodernist fiction, there is anxiety that historical concerns such as the scale of violence in the Second World War, the Nazi genocide, the paranoiac politics of the Cold War and European colonialism have made fiction a medium for history. Chinua Achebe's novels, indeed, are manifestation of colonialism and its subsequent impact on the literary text and dominant discourse. In exploring these terms, this dissertation endeavors to closely examine Gayatri Spivak's concept of subaltern in the Chinua Achebe's Things Fall Apart and No Longer at Ease. Furthermore, the present paper demonstrates Spivak's voice to differences: that is, class categorization and marginalized subaltern subjects. By the emergence of colonialism, the significance of social class and social discourse became predominant; therefore, colonial discourses instilled into the social, cultural construction and literary text, particularly novel. In this regard, the investigation of the dominate discourses is pursued, and this helps to show how colonialism resulted in discourse inculcation. The resistant perspective against ruling ideology, as the Italian Marxist political activist, Antonio Gramsci calls it cultural hegemony is presented through language, tradition, and customs. Finally, the study focuses on Marxist concept of false consciousness from the viewpoint of Antonio Gramsci to Louis Althusser.
\end{abstract}

Keywords: Colonial discourse, Subaltern, False Consciousness, Social Class, Change and Tradition, Language, Culture 1. Female subaltern

The present research study attempts to investigate Chinua Achebe's Things Fall Apart and No Longer at Ease in terms of Gayatri Spivak Marxist-Post colonialist conceptions of the subaltern, colonial discourse and false consciousness. Gayatri Spivak is one of the leading figures associated with contemporary cultural and critical theories to challenge the "legacy of colonialism" and the way readers engage with literature and culture. Spivak represents the voice of difference, however other pos-tcolonialist theoreticians such as Bahabha and Said ignore the concept of difference. Beside difference, the notion of social class is one of her major subcategories. She has frequently focused on what in postcolonial studies has come to be called the subaltern.

The consequences of this consideration to difference is Spivak focus on the female subaltern. She argues,' In the context of colonial production, the subaltern has no history and cannot speak, the subaltern as female is even more deeply in shadow'. Spivak in New Nation Writers Conference in South Africa (1992) argued:

"subaltern is not just a classy word for “oppressed", for [the] Other, for somebody who's not getting a piece of the pie. . . . In post-colonial terms, everything that has limited or no access to the cultural imperialism is subaltern - a space of difference. Now, who would say that's just the oppressed? The working class is oppressed. It's not subaltern. . . . Many people want to claim subalternity. They are the least interesting and the most dangerous. I mean, just by being a discriminated-against minority on the university campus; they don't need the word 'subaltern'",

In the famous essay from 1988, "' can the subaltern speak?", Spivak as she observes colonial subject, studies the nineteenth- century notion of what she calls" widow sacrifice"' disputes about the colonized Indians and their British colonizers and concludes that neither party allowed women to speak. The British text has made a position for woman as what she called"' Western individualism" which accentuates on civilization and modern freedom, on the other hand, the Indian ones represent her best medium for duty which is enrooted in tradition. In all sides, the woman themselves remain unheard.

${ }^{1}$ The Legacy of Colonialism: A Model of Africa's Underdevelopment March 1, 2002 
In the Ibo society women are considered to be minor subordinate as compared to men. However, they are play significant roles in the Ibo society. Generally, women in this society tends to be very weak, without power and useless. The enormous significance is shown about the women's role in the Ibo society that is men in the Ibo society beat women and despise them in great extent, and the role such as caretakers of their crops, educators of their children and householders are means of using women for men purposes and indoctrinate women false consciousness about their statue quo.

Some examples clearly show the role of women in Ibo society. When Okonkwo beats his second wife just for this reason that the meal is not prepared. In Ibo society, beating is allowed to show man power. Women are the weaker sex, and are made to bear children. 'He walked back to his obi to await Ojiugo's return. And when she returned he beat her very heavily.....'. Men in Ibo society scold women for even a little bit mistakes. A woman had no authority and justice and. It is obvious that "Okonkwo ruled his household with a heavy hand. All his wives, especially the youngest, lived in perpetual fear of his fiery temper (Achebe)." It explains that women roles in the Ibo society is that of submissive wife.

The protagonist in the novel is mostly obsesses with notion of hyper-masculine and depreciates anything feminine. The gender theme in the book revolves around the idea of balance between masculine and feminine forces. Okonkwo's life was dominated by fear and weakness. He did not intend to take after his father Unoka, because he embodied the epitome of failure. Ibo society attributes power and courage to men and anything weak to women. The descriptions of his tribe is masculine. "a chick that will grow into a cock can be spotted the very day it hatches, I have done my best to make Nwoye grow into a man, but there is much of his mother in him'. According to this quote Ibo's son from his first wife, reminds Okonkwo of his father Unoka as he describes him as woman-like. "'if Ezinma had been a boy I would have been happier'. More ever; he even wishes that his daughter Ezinma should have been a boy. As you observe the voice of women has been underestimated during the novel.

"'Greatness is now in the things of the white man." In No Longer at Ease, Obi's identity is constructed by two forces: Western culture and Igbo's values. Odogwu attracted to Western values and to Christianity, therefore his decision alienates him from his traditional African culture. The feeling of progress and modernity as Odogwu feels represents Odogwu's lament for the lack of true greatness in his own people. This shows that the identity of African is still unbalanced and considered their own culture as unprivileged and marginalized.

Spivak argues that the representation of the various lower-class subaltern groups was framed in the terms and interests of the ruling power, or dominant social class. In the British Empire, the lives of the rural people in India were subordinated to imperial governance. As Ranajit Guha ${ }^{2}$ explains in On Some Aspects of the Historiography of Colonial India

"The historiography of Indian nationalism has for a long time been dominated by elitism and bourgeois nationalist elitism. Both originated as the ideological product of British rule in India, but have survived the transfer of power and have been assimilated to neo-colonialist and neo-nationalist forms of discourse in Britain and India respectively",

The postcolonial literary critic Neil Lazarus ${ }^{3}$ has argued that Spivak is not really concerned with native agency at all, but a theory of practice of the disenfranchised elements of the native population are represented.

\section{Colonial discourse}

Spivak converges postcolonial perspectives with Marxist to class differentiating factor. In associating with colonial text, she tries to demonstrate how dominant class ideology resulted in false assumption between colonizers and colonized. By the emergence of colonialism, the significance of social class and social discourse became predominant; therefore, colonial discourses instilled into the social, cultural construction and literary text, particularly novel. The post-colonial theory bases itself on the post-modernist frame and Homi Bhabha, one of the most important figures in contemporary post-colonial studies, echoes the post-modernist view concerning colonial discourse:

"Colonial discourse is an apparatus of power, turns on the recognition and disavowal of racial/cultural/historical differences." [ibid, p.70] It appears that in such studies the intrinsic heterogeneity of discourses is a consequence of "the structure of symbolic representation."

Colonialism of culture is very clearly seen as integral part in Things Fall Apart. As white men enter the village, they try to change the culture of Igbo and turning them to the Christian. Gradually the white men influence the power of Christianity as a significant religious factor. Things Fall Apart tells about Okonkwo struggles with contradictions, culture conflict, mainly the clash between Igbo tradition and Christian doctrine. Achebe describes white man as source of hegemony ${ }^{4}$.

In No Longer at Ease, obi is involved in two worlds: the world of traditional Africa and changing world. He was well educated and studied law to help his people in law case but Obi eventually changed his course of study from law to English. As he is attracted to colonial discourse, he finds himself alienated which shattered his identity to be no longer

\footnotetext{
${ }^{2}$ Ranajit Guha is a historian of South Asia who was greatly influential in the Subaltern Studies group, and was the editor of several of the group's early anthologies

${ }^{3}$ Professor Neil Lazarus is Professor, and teaches on the English and Comparative Literary Studies program.

${ }^{4}$ The resistant perspective against ruling ideology, as the Italian Marxist political activist, Antonio Gramsci calls it cultural hegemony is presented through language, tradition, and customs
} 
at ease. "The traders burst into song again Obi knew the refrain, he tried to translate it into English, and for the first time its real meaning dawned on him' this quote explains the concept of language which Obi cannot understand until he translated it into English.

Spivak has also shown that the rhetorical texts question and challenge the authority of colonial master narratives. Actually, for Spivak European colonialism is based on the use of culture as a form of rhetoric. Spivak draws attention to the theories of deconstructive critic Paul de Man ${ }^{5}$. Spivak argues that "the basis of a truth claim is no more than a trope'. Spivak argues that the suppression of rhetoric can have devastating consequences in social and political matters. Spivak carefully follows the rhetoric of those texts to where ideas, concepts, or metaphors are used in broad historical and geographical context of imperialism.

The anthropologist G. T. Basden ${ }^{6}$ writes that "it is a practical impossibility for the European to comprehend fully the subtleties of the native character" .Colonialism denies the history of native and tries to suppress language, religious, racial, genetic, ethnic, cultural or institutional dominance. Gikandi ${ }^{7}$ even calls Umuofia a "community in which mastery of figurative language is the core to social survival and control". It shows that one of the feature of the Igbo society is the importance of proverbs and stories. Achebe tries to use the rhythms, structures, and beauty of the Igbo language in order to emend the portrait of Africa that was painted by so many writers of the colonial period.

According to $\mathrm{Gramsci}^{8}$ the bourgeoisie constructs and maintains what he calls hegemony which is concepts, values and meanings that shape meaning and define reality for majority of people. Because the bourgeoisie actually control the economic base and establish all the elements like that of music, literature, art and etc. They gain the spontaneous appraisal of working class. The working people themselves give their consent to bourgeoisie and adopt bourgeoisie values and beliefs and this shapes individual consciousness. Spivak in 'can the subaltern speak?' explains;

"'Antonio Gramsci's work on the "'subaltern class" extends the class position/ class consciousness argument isolated in The Eighteenth Brumairi. Perhaps because Gramsci criticized the vanguardistic position of Leninist intellectual, he is concerned with intellectual role in the subaltern culture and political movement into hegemony. This movement must be made to determine the production of history as narrative (of truth)"'.

Colonial discourse and hegemony happens when white men came to their village. White missionaries realized that it is impossible to get more converts by their belief which were based on falsehood. So they planned to hail the subject ${ }^{9}$ and to divert the mind of Igbo people so they decide to make schools and hospitals based on colonial concepts. In the novel Mr. Brown learnt about the Igbo religion from his friend, Akunna, who had sent his son to learn white men's knowledge. Therefore they started to teach the customs and culture of Christianity which show the integral parts of oppression by education.

\section{False consciousness}

"False consciousness" is a notion taken from Marxist theory of social class. The concept shows misrepresentation of dominant social relations in the consciousness of working classes. Marx himself did not use the phrase "false consciousness," but he paid broad attention to the concept of ideology. Marx's theory of ideology is presented in The German Ideology (Marx and Engels) ${ }^{10}$. Marx uses the term "ideology" to refer to a system of ideas through which people understand their world. In Marx's writings "ideology" and thought are based on the material circumstances which result in determining consciousness.

Althusser ${ }^{11}$ believes prevailing ideology or hegemony forms the thoughts of people through a process he calls interpellation or hailing the subject which is ideology power to give individuals identity. He argues that the dominate can use military and police force to repress the working class but colonizers in order to maintain and stabilize their power, they choose the use the Ideological State Apparatus ${ }^{12}$ or hegemony.

According to Gramsci, ideology and power are fundamentals for the ruling classes to succeed in controlling society: they maintain their power not only through domination, but also through moral and intellectual leadership. Gramsci

\footnotetext{
${ }^{5}$ Paul de Man, born Paul Adolph Michel Deman, was a Belgian-born literary critic and literary theories

${ }^{6} \mathrm{G} \mathrm{T}$ Basden Is the author of books such as Among the Ibos Of Nigeria

${ }^{7}$ Simon Gikandi is Robert Schirmer Professor of English at Princeton University and editor of PMLA, the official journal of the Modern Languages Association (MLA).

${ }^{8}$ Antonio Gramsci was an Italian neo-Marxist theorist and politician. He wrote on political theory, sociology and linguistics

${ }^{9}$ Interpellation was described by Althusser in his reinterpretation of Marxism and the position of the subject. He explained how Ideological State Apparatuses interpellated the subjects into ideological positions.

10 The German Ideology is a set of manuscripts written by Karl Marx and Friedrich Engels around April or early May 1846. Marx and Engels did not find a publisher.

${ }^{11}$ Louis Pierre Althusser was a French Marxist philosopher. He was born in Algeria and studied at the École Normale Supérieure in Paris, where he eventually became Professor of Philosophy

12 The Ideological State Apparatuses pertains to churches, schools, families, etc. Instead of expressing and imposing order, through repression, the Ideological State Apparatuses reinforce the rule of the dominant class, principally through ideology
} 
believes that ideology is a set of ideas and representations which bind people together. He argues that hegemony creates a kind of unity between classes and political parties, because ideology and power are inseparable:

Individuals are actively involved in their own conditioning, but also that ideology is therefore diverse, embodied in material practices rather than unified monolithically according to class

Significance of Althusser and Gramsci theories clarify the fact that how people's ideology and individual consciousness are shaped and how the concept of false consciousness alienates individuals' values, particularly proletariats, also called wage slaves throughout the novels. They elucidate the conflict between social classes and play great roles in showing that how these conflicts are constructed and who is in the dominate power for creating such conflicts.

In applying the meaning of Achebe's works directly to the domain of Marxist-postcolonialist theories, the novels help to elucidate the position of social class and construction of subject formation in relationship between colonizers and colonized. The dominant ideology which is ubiquitous in the novels shows the construct of colonizer's superiority and the colonized inferiority. This ideology creates its own discourse in the colonial enterprise, particularly the literary text and inculcates false consciousness in shaping and controlling each person's self-definition and class consciousness.

Achebe's writing is mainly designed to show the failure of Nigeria's people to have plan and thought's independence. The depiction of ordinary Nigerians in the novel becomes much more complex. Nanga and Odili in $A$ Man of the $P_{\text {People }}^{13}$ are two good examples of ignorant characters who are paralyzed by false consciousness. They are unaware of their existence and disillusioned with current status quo.

Things Fall Apart portrays racial encounters between whites and Igbo people. The notion of hegemony shows the conquest of the Igbo by bringing education. The white colonizers basically use culture, education and new methods of learning to dominate the Igbo people. They construct schools and educational center based on colonizer's thought and even include the women in educative disciplines. The colonial power by means of education help conquer the Igbo's Mind. Therefore they get involved in learning through the colonial educational system which results in Igbo's identity crisis to underestimate aboriginal culture and customs through inculcation of false consciousness. This false consciousness changes the mentality of Igbo women:

It was Wednesday in Holy Week and Mr. Kiaga had asked the women to bring red earth and white chalk and water to scrub the church for Easter, and the women had formed themselves into three groups for this purpose. They set out early that morning, some of them with their water-pots to the stream, another group with hoes and baskets to the village earth pit, and the others to the chalk quarry.

In Postcolonialism, Psychoanalysis and Burton: Power Play of Empire, Ben Grant (2009) explains the racial aspect of colonial hegemony: "if the trope of a racialised space institutes clear borders between different races, the temporal nonetheless returns as an ambivalent factor in the institution of these boundaries: by positing the negro as inferior, by which is meant backward"

\section{Conclusion}

Postcolonialism along with Marxism shows the significance of how the emergence of colonialism occurs and how the significance of social class and social discourse become predominant. It shows that colonial discourses instilled into the social, cultural construction and literary text, particularly novel. In this regard, the investigation of the dominate discourses helps to show how colonialism resulted in discourse inculcation. The resistant perspective against ruling ideology, as the Italian Marxist political activist, Antonio Gramsci calls it cultural hegemony is presented through language, tradition, and customs. By delving into the dominant power and these resistant elements in obliteration of colonial discourse, ones understands the attitudes of resistance and realizes identity formation.

In fact people's ideology and individual consciousness are shaped and concept of false consciousness alienates individuals' values, particularly proletariats, also called wage slaves throughout the novels. They elucidate the conflict between social classes and play great roles in showing that how these conflicts are constructed and who is in the dominate power for creating such conflicts.

\section{References:}

Achebe, C. (2010). An Image of Africa: And, The Trouble with Nigeria. London: Penguin.

Alam, M. (2014). Reading Chinua Achebe's Things Fall Apart from the Postcolonial Perspective. Research on Humanities and Social Sciences, 4(12), 102-106

Althusser, L. (1971). Lenin and philosophy, and other essays. [London]: New Left Books.

Basden, G.T. (1966). Among the Igbos of Nigeria. First Published in 1966. Routledge is an imprint of Taylor \& Francis Gramsci, Antonio. (1971). Selections from the Prison Notebooks of Antonio Gramsci. Translated by Q. Hoare and G. Nowell-Smith. New York: International.

Ashcroft, B., Griffiths, G., \& Tiffin, H. (2000). Postcolonial Studies: The Key Concepts. London: Routledge.

${ }^{13}$ A Man of the People is the fourth novel by Chinua Achebe in 1966. This novel is satirical .It shows this novel foreshadows the Nigerian coups of 1966. 
Grant, B. (2009). Postcolonialism, Psychoanalysis and Burton: Power Play of Empire. New York: Routledge.

Gandhi, L. (1998) Postcolonial Theory: A Critical Introduction, New York and Chichester: Columbia University Press. Marx, K., and Engels, F. [1845-49] (1970). The German ideology. 3d rev. ed. Moscow: Progress Publishers.

McLeod, J. (2000) Beginning Postcolonialism, Manchester: Manchester University Press

Spivak, G. C. (2010). Can the Subaltern Speak?: Reflections on the History of an Idea. New York: Columbia University Press.

Spivak, G.C. (1995) Imaginary Maps, (translation with critical introduction of three stories by Mahasweta Devi), New York: Routledge

Spivak, G.C. (1999) A Critique of Postcolonial Reason: Towards a History of the Vanishing Present, Cambridge: Harvard University Press; Calcutta:Seagull Press. 